University of Nebraska - Lincoln

DigitalCommons@University of Nebraska - Lincoln

USDA Wildlife Services - Staff Publications

U.S. Department of Agriculture: Animal and Plant Health Inspection Service

2021

\title{
H7N1 Low Pathogenicity Avian Influenza Viruses in Poultry in the United States During 2018
}

\author{
Dong-Hun Lee \\ University of Connecticut - Storrs, dong-hun.lee@uconn.edu \\ Mary Lea Killian \\ USDA APHIS
}

Thomas J. DeLiberto

U.S. Department of Agriculture, Thomas.J.DeLibertot@aphis.usda.gov

Xiu-Feng Wan

University of Missouri, Columbia, wanx@missouri.edu

Li Lei

Mississippi State University

Follow this and additional works at: https://digitalcommons.unl.edu/icwdm_usdanwrc

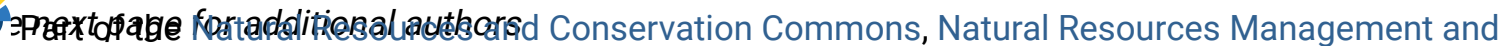
Policy Commons, Other Environmental Sciences Commons, Other Veterinary Medicine Commons, Population Biology Commons, Terrestrial and Aquatic Ecology Commons, Veterinary Infectious Diseases Commons, Veterinary Microbiology and Immunobiology Commons, Veterinary Preventive Medicine, Epidemiology, and Public Health Commons, and the Zoology Commons

Lee, Dong-Hun; Killian, Mary Lea; DeLiberto, Thomas J.; Wan, Xiu-Feng; Lei, Li; Swayne, David E.; and Torchetti, Mia Kim, "H7N1 Low Pathogenicity Avian Influenza Viruses in Poultry in the United States During 2018" (2021). USDA Wildlife Services - Staff Publications. 2463.

https://digitalcommons.unl.edu/icwdm_usdanwrc/2463

This Article is brought to you for free and open access by the U.S. Department of Agriculture: Animal and Plant Health Inspection Service at DigitalCommons@University of Nebraska - Lincoln. It has been accepted for inclusion in USDA Wildlife Services - Staff Publications by an authorized administrator of DigitalCommons@University of Nebraska - Lincoln. 


\section{Authors}

Dong-Hun Lee, Mary Lea Killian, Thomas J. DeLiberto, Xiu-Feng Wan, Li Lei, David E. Swayne, and Mia Kim Torchetti 


\title{
H7N1 Low Pathogenicity Avian Influenza Viruses in Poultry in the United States During 2018
}

\author{
Dong-Hun Lee, ${ }^{\text {ABK }}$ Mary Lea Killian, ${ }^{\mathrm{C}}$ Thomas J. Deliberto, ${ }^{\mathrm{D}}$ Xiu-Feng Wan, ${ }^{\mathrm{EFGHIJ}}$ Li Lei, ${ }^{\mathrm{J}}$ David E. Swayne, ${ }^{\mathrm{B}}$ \\ and Mia Kim Torchetti ${ }^{\mathrm{C}}$
}

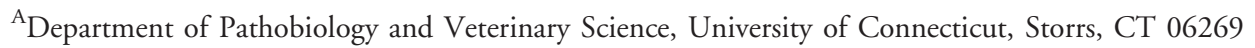 \\ ${ }^{B}$ United States National Poultry Research Center, Agricultural Research Service, United States Department of Agriculture, Athens, GA 30605 \\ ${ }^{C}$ National Veterinary Services Laboratories, Diagnostics and Biologics, Veterinary Services, Animal and Plant Health Inspection Service, \\ United States Department of Agriculture, Ames, IA 50010 \\ ${ }^{D}$ National Wildlife Research Center, Wildlife Services, Animal and Plant Health Inspection Service, United States Department of Agriculture, \\ Fort Collins, CO 80521 \\ ${ }^{\mathrm{E}} \mathrm{MU}$ Center for Research on Influenza Systems Biology, University of Missouri, Columbia, MO, 65211 \\ F Department of Molecular Microbiology and Immunology, School of Medicine, University of Missouri, Columbia, MO 65211 \\ ${ }^{\mathrm{G}}$ Bond Life Sciences Center, University of Missouri, Columbia, MO, 65211 \\ ${ }^{\mathrm{H}}$ Department of Electrical Engineering \& Computer Science, College of Engineering, University of Missouri, Columbia, MO, 65211 \\ ${ }^{\mathrm{I}}$ MU Institute for Data Science and Informatics, University of Missouri, Columbia, MO, 65211 \\ ${ }^{\mathrm{J}}$ Department of Basic Sciences, College of Veterinary Medicine, Mississippi State University, Mississippi State, MS 39762
}

Received 28 July 2020; Accepted 1 October 2020; Published ahead of print 1 October 2020

\begin{abstract}
SUMMARY. Here, we report three detections of H7N1 low pathogenicity avian influenza viruses (LPAIV) from poultry in Missouri $(n=2)$ and Texas $(n=1)$ during February and March 2018. Complete genome sequencing and comparative phylogenetic analysis suggest that the H7 LPAIV precursor viruses were circulating in wild birds in North America during the fall and winter of 2017 and spilled over into domestic poultry in Texas and Missouri independently during the spring of 2018.
\end{abstract}

\begin{abstract}
RESUMEN. Nota de investigación —Virus de la influenza aviar de baja patogenicidad H7N1 en avicultura, Estados Unidos, 2018.

En este artículo se reportan tres detecciones del virus de influenza aviar de baja patogenicidad H7N1 (LPAIV) en avicultura en Missouri $(n=2)$ y Texas $(n=1)$ durante febrero y marzo del 2018. La secuenciación completa del genoma y el análisis filogenético comparativo sugieren que precursores de este virus de influenza de baja patogenicidad H7 circulaban en aves silvestres en América del Norte durante el otoño y el invierno de 2017 y se propagaron a las aves comerciales en Texas y Missouri de forma independiente durante la primavera del 2018.

Key words: low pathogenicity avian influenza virus, H7N1, poultry, phylogenetic analysis, avian influenza virus, influenza A virus

Abbreviations: $\mathrm{HA}=$ hemagglutinin; HPAIV = high pathogenicity avian influenza viruses; IVPI = intravenous pathogenicity index; LPAIV = low pathogenicity avian influenza viruses; TMRCA = time to the most recent common ancestor
\end{abstract}

High pathogenicity avian influenza viruses (HPAIV) have devastating impacts on the poultry industries and are of public health concern (1). With infections in avian species, $\mathrm{H} 5$ and $\mathrm{H} 7$ low pathogenicity avian influenza viruses (LPAIV) can mutate to HPAIV through changes in the hemagglutinin (HA) cleavage site.

Here, we report three detections of H7N1 LPAIV from poultry in Missouri and Texas during February and March 2018. Detections from all three farms were made through routine premovement testing of either birds or eggs (2). The first detection was in commercial turkey flock samples collected on February 26, 2018, in Jasper County, MO, followed by the second detection in a broiler breeder flock in Hopkins County, TX, on March 2, 2018. The third detection was in a backyard flock on March 14, 2018, in Webster County, MO. Complete genome sequencing and comparative phylogenetic analysis of these H7N1 LPAIV were conducted to better understand both the source, as well as the genetic relatedness, among other North American $\mathrm{H} 7$ events in poultry.

\footnotetext{
${ }^{\mathrm{K}}$ Corresponding author. E-mail: dong-hun.lee@uconn.edu
}

\section{MATERIALS AND METHODS}

The intravenous pathogenicity index (IVPI) test was conducted according to the World Organisation for Animal Health Manual of Diagnostic Tests and Vaccines for Terrestrial Animals (3). Three representative $\mathrm{H} 7 \mathrm{~N} 1$ viruses, including one representative virus from each site (A/chicken/Texas/18-007912-002/2018, A/chicken/Missouri/ 18-008648-001/2018, and A/turkey/Missouri/18-008108-011/2018), were inoculated into chickens. Briefly, $0.1 \mathrm{ml}$ of infectious allantoic fluid was inoculated intravenously into ten 6 -wk-old specific-pathogenfree chickens, and the chickens were monitored for 10 days for morbidity and mortality. Isolates with IVPI $>1.2$ were characterized as HPAIV. The challenge studies and all experiments with live viruses were conducted in a Biosafety Level 3 facility at the National Veterinary Services Laboratories, Animal and Plant Health Inspection Service, U.S. Department of Agriculture in Ames, IA, and in accordance with approved Institutional Animal Care and Use Committee protocols.

Viral RNA from eight H7N1 viruses was amplified by reverse transcription PCR and sequenced by using the Illumina MiSeq platform, as described elsewhere (4). De novo and directed assembly of genome sequences were carried out by using IRMA version 0.6.7 (5), followed by DNASTAR SeqMan NGen (6). Complete genome 

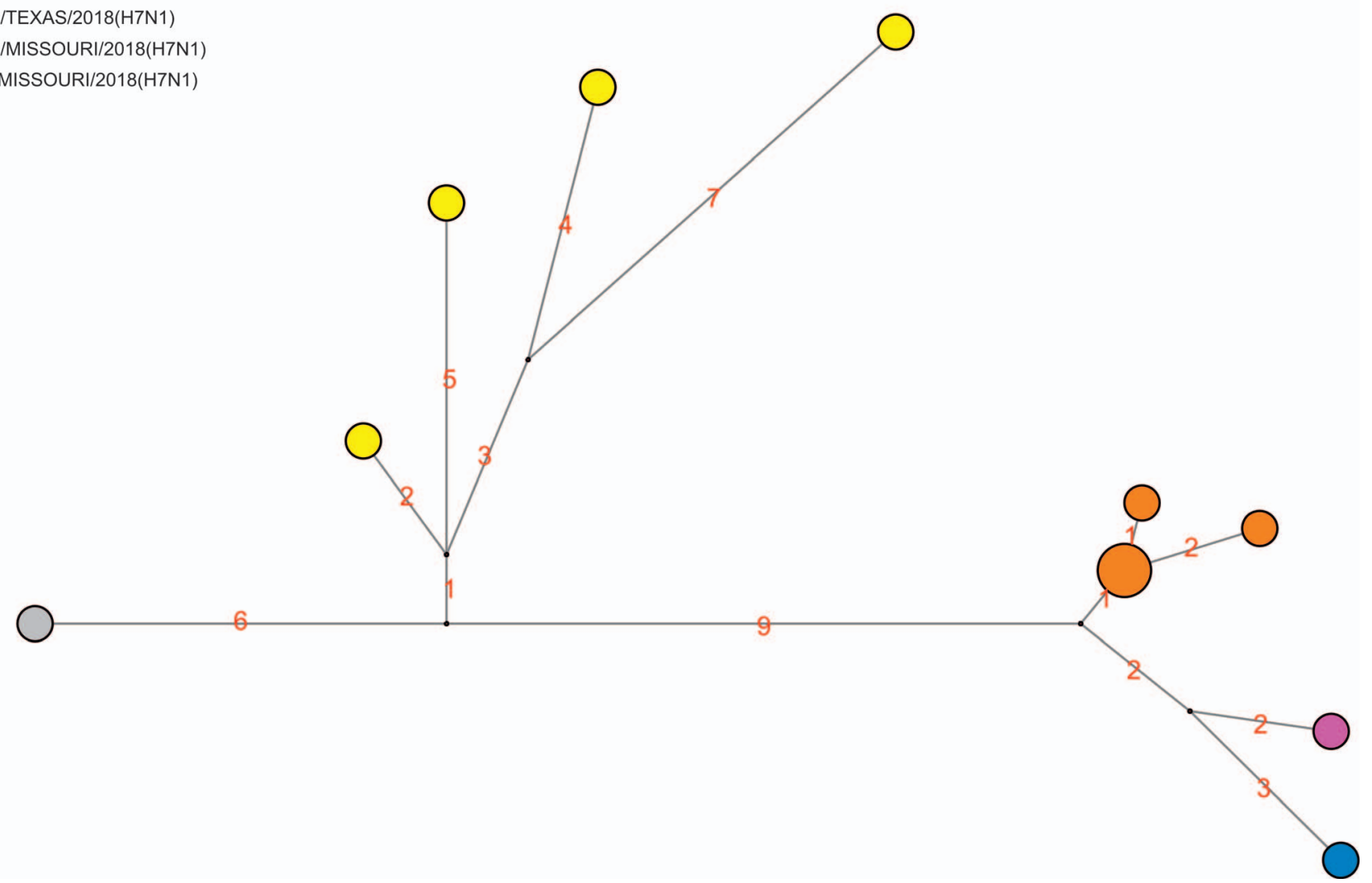

Fig. 1. Time-scaled Bayesian maximum clade credibility tree for HA gene. Blue node bars represent 95\% Bayesian credible intervals (BCI). Posterior probabilities of nodes are indicated by the size and color of circles at each node. The estimated mean TMRCA of 2018 H7N1 viruses are indicated.

sequences have been deposited in GenBank under accession numbers MT658131-MT658194.

All available complete genome sequences of contemporary avian influenza viruses identified from North America were retrieved from the Influenza Virus Resource database (http://www.ncbi.nlm.nih.gov/ genomes/FLU/FLU.html) on April 9, 2018. The nucleotide sequences obtained in this study were added to the data set. Nucleotide sequences were aligned by using MAFFT (7). Maximum likelihood phylogenies of each gene segment were reconstructed by using RAxML (8). A gamma model of rate heterogeneity and a generalized time-reversible substitution model were used (9). Bootstrap support values were generated by using 1000 rapid bootstrap replicates. As described in Li et al. (10), a progenitor gene and a potential precursor virus were inferred when the following criteria were met: 1) the candidate gene segment shared a phylogenetic clade with a minimum bootstrap value of 70 with a poultry gene segment from the current event; 2) the candidate progenitor gene segment and poultry gene segment shared $>98 \%$ nucleotide sequence identity; 3) the candidate gene segment shared the highest nucleotide sequence identity with the poultry-origin influenza A virus gene segment in its genetic cluster; and 4) the putative progenitor gene segment was detected prior to detection of the poultry origin gene segment. A potential precursor virus was inferred when a virus had three or more possible progenitor gene segments from an $\mathrm{H} 7$ virus identified in North American poultry.

Bayesian relaxed clock phylogenetic analysis of the HA gene was performed by using BEAST version 1.8.3 (11). We applied an uncorrelated lognormal distribution relaxed clock method, the Hasegawa-Kishino-Yano nucleotide substitution model, and the Gaussian
Markov random field Bayesian skyride coalescent prior (12). A Markov chain Monte Carlo method to sample trees and evolutionary parameters was run for 50 million generations. At least three independent chains were combined to ensure adequate sampling of the posterior distribution of trees. The BEAST output was analyzed with TRACER (13) with $10 \%$ burn-in. A maximum clade credibility tree was generated for each data set by using TreeAnnotator in BEAST. We estimated the mean time to the most recent common ancestor (TMRCA) of the ancestral node of $\mathrm{H} 7 \mathrm{~N} 1$ viruses. FigTree (14) was used for visualization of trees. Branches were colored according to migratory bird flyways (Pacific, Central, Mississippi, and Atlantic) and 2018 H7N1 outbreak strain. To better visualize the genetic relatedness of viruses, phylogenetic network analysis of the HA gene was conducted by using the medianjoining method implemented by Network version 5.0 with epsilon set to $0(15)$.

\section{RESULTS AND DISCUSSION}

Three representative isolates were of low pathogenicity in chickens on intravenous inoculation (IVPI $=0.0$ ). In addition, we examined the HA cleavage site, PENPKTR/G, which is typical for LPAIV (1). All H7N1 viruses were considered LPAIV on the basis of IVPI and the amino acid sequence at the HA cleavage site.

All available $\mathrm{H} 7 \mathrm{~N} 1$ poultry isolates from two premises in Missouri and one in Texas shared high levels of nucleotide identity, varying from $99.4 \%$ to $99.6 \%$ for each individual gene segment. Phylogenetic analyses were conducted to better understand both the 
Table 1. Possible progenitor gene segments of H7N1 LPAIV identified in Texas and Missouri.

\begin{tabular}{llr}
\hline Segment $^{\mathrm{A}}$ & \multicolumn{1}{c}{ Virus strain } & Nucleotide sequence identity (\%) \\
\hline PB2 & A/gadwall/Iowa/AH0130314/2017(H5N2) & 99.52 \\
PB1 & A/mallard/Ohio/15OS5649/2015(H10N1) & 99.48 \\
PA & A/emperor goose/Alaska/UGAI156758/2015(H3N8) & 99.32 \\
HA & A/blue winged teal/Louisiana/UGAI170860/2017(H7N3) & 99.24 \\
NP & A/American black duck/Ohio/15OS0658/2016(H7N3) & 99.09 \\
NA & A/blue winged teal/Illinois/15OS6152/2015(H3N1) & 99.37 \\
M & A/gadwall/North Dakota/AH0149892/2017(H5N2) & 99.80 \\
NS & A/northern shoveler/Missouri/14OS4367/2014(H10N7) & 99.88 \\
\hline
\end{tabular}

${ }^{\mathrm{A}} \mathrm{M}$, matrix; NA, neuraminidase; NP, nucleoprotein; NS, non-structural; PA, polymerase acidic; PB, polymerase basic.

source, as well as the genetic relatedness among other $\mathrm{H} 7$ events in domestic poultry. Results suggested these H7N1 LPAIV belong to North American lineage in the trees of $\mathrm{H} 7, \mathrm{~N} 1$, and all six internal genes, and all gene segments are genetically close to those viruses from wild birds, supporting a wild bird-origin virus (Fig. 1 and Supplemental Fig. S1). The ML and Bayesian phylogenies of the HA segment clearly indicate that these H7N1 LPAIV were distinct from the viruses caused the $2016 \mathrm{H} 7 \mathrm{~N} 8$ (Indiana) and $2017 \mathrm{H} 7 \mathrm{~N} 9$ (Tennessee, Alabama, Georgia, and Kentucky) poultry outbreaks (Supplemental Figs. S1d, S2) $(16,17,18)$. The HA segment of H7N1 poultry isolates from Missouri and Texas had 97.6\%-97.8\% nucleotide identity with the $2016 \mathrm{H} 7 \mathrm{~N} 8$ viruses and $97.7 \%-98.3 \%$ nucleotide identity with the 2017 H7N9 viruses. Although a possible wild bird-origin influenza progenitor gene was identified for each individual gene segment (Table 1), no wild bird-origin influenza precursor virus with all eight gene segments was identified for these $\mathrm{H} 7 \mathrm{~N} 1$ viruses, possibly due to limited availability of recent data for the wild bird-origin subtype $\mathrm{H} 7$ avian influenza viruses.
The phylogenetic network analysis also supported the close genetic relationship among the HA gene from viruses detected in domestic poultry in Texas and Missouri (Fig. 2).

Molecular dating analyses suggested the TMRCA of the H7N1 HA gene was estimated to be November 3, 2017 (95\% Bayesian credible interval: August 9, 2017, to January 4, 2018). It is likely that the H7 LPAIV precursor viruses were circulating in wild birds in North America during fall and winter of 2017 and spilled over into domestic poultry in Texas and Missouri during the spring of 2018.

Identified risk factors for introduction of LPAIV into commercial poultry farms include the presence of wildlife and waterfowl near poultry barns, housing conditions, and breaches in biosecurity protocol. Following the response to detections of LPAI H7N1 in three different counties across Texas and Missouri, genetic and epidemiologic investigations were conducted to determine potential relationships across the apparently unrelated facilities. The commercial farms involved different production types (chicken vs.

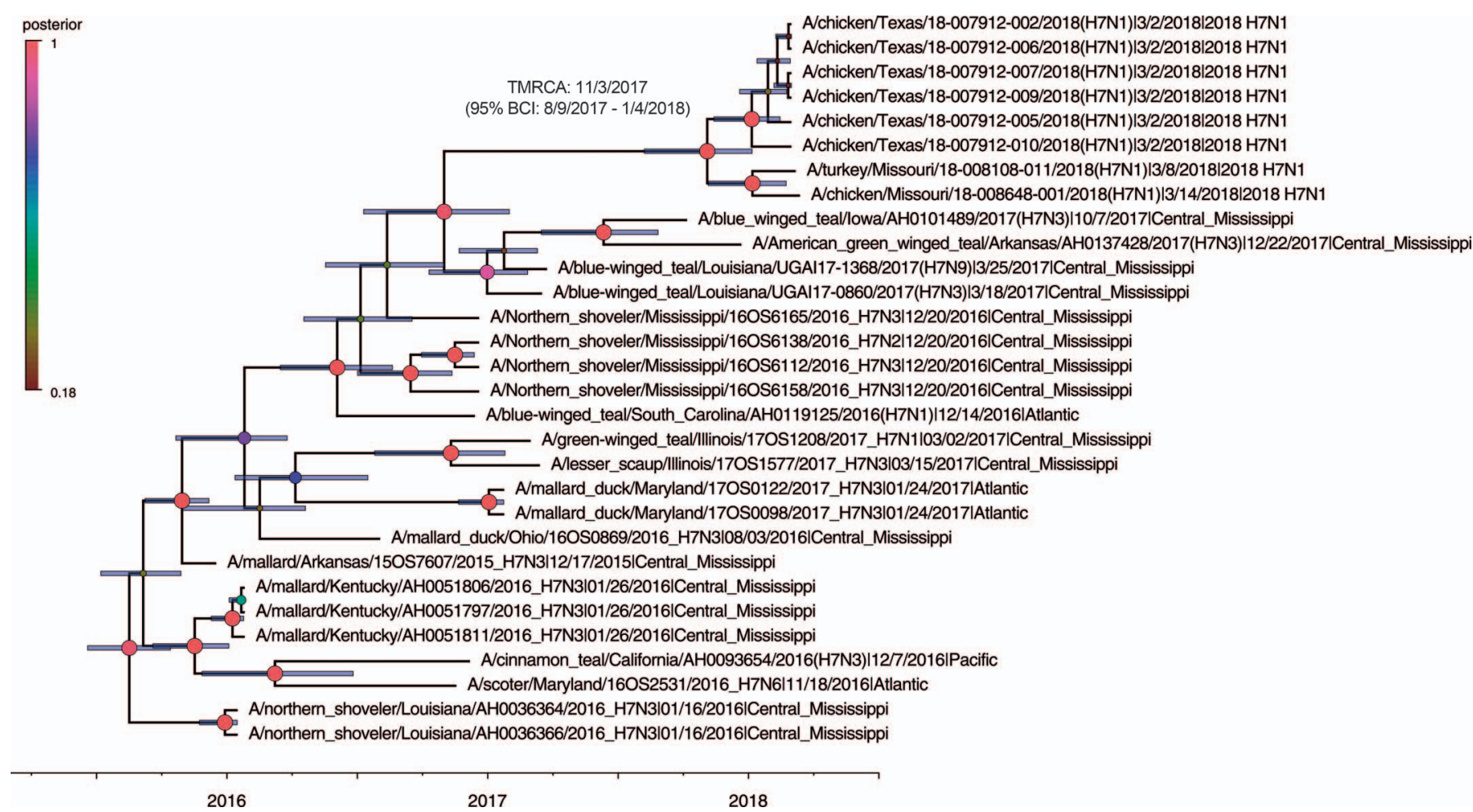

Fig. 2. Median-joining phylogenetic network of the HA gene. This network includes all of the most parsimonious trees linking the sequences. Each unique sequence is represented by a circle sized relative to its frequency. The number of nucleotide differences between viruses is indicated on the branches. Isolates are colored according to the origin of strains. 
turkey) and different integrated poultry companies, implying distinct sources of birds, transport trucks, crews, and feed. The epidemiologic studies suggested that the LPAIV were introduced independently from wild birds to poultry in Missouri and Texas. A similar virus being subsequently detected in a backyard operation lends support to the evidence that the outbreak was caused by environmental exposure (2).

Wild bird-origin $\mathrm{H} 7$ viruses have spilled over repeatedly to poultry $(1,16,17,18,19)$. During 2016 to 2017, introductions of wild bird-origin $\mathrm{H} 7$ viruses resulted in LPAIV that mutated into HPAIV after circulation in poultry in the United States, highlighting the need for early detection and early elimination of H5 and H7 LPAIV in poultry $(16,17,18)$. Given the potential to mutate into HPAIV, the present study shows how routine active surveillance in poultry and wild birds is important and necessary for monitoring and control of $\mathrm{H} 5$ and $\mathrm{H} 7$ viruses.

Supplemental data associated with this article can be found at https://doi.org/10.1637/aviandiseases-D-20-00088.s1.

\section{REFERENCES}

1. Lee DH, Criado MF, Swayne DE. Pathobiological origins and evolutionary history of highly pathogenic avian influenza viruses. Cold Spring Harb Perspect Med. a038679; 2020.

2. [USDA-APHIS] U.S. Department of Agriculture, Animal and Plant Health Inspection Service. Epidemiologic and Other Analyses of Avian Influenza Affected Poultry Flocks May 25, 2018 Report. USDA-APHIS. Fort Collins, CO [accessed 2020 Jul 28]. https://www.aphis.usda.gov/animal_ health/animal_diseases/avian/downloads/analysis2018.pdf; 2018.

3. [OIE] World Organisation for Animal Health. Chapter 3.3.4. Avian influenza (infection with avian influenza viruses). In: Manual of diagnostic tests and vaccines for terrestrial animals. Paris (France): OIE [accessed 2020 Jul 28] https://www.oie.int/fileadmin/Home/eng/Health_standards/tahm/3. 03.04_AI.pdf; 2018.

4. Lee DH. Complete genome sequencing of influenza A viruses using next-generation sequencing. Methods Mol Biol. 2123:69-79; 2020.

5. Shepard SS, Meno S, Bahl J, Wilson MM, Barnes J, Neuhaus E. Viral deep sequencing needs an adaptive approach: IRMA, the iterative refinement meta-assembler. BMC Genomics 17:708; 2016.

6. SeqMan NGen ${ }^{\circledR}$. Version 14. DNASTAR. Madison, WI. https:// www.dnastar.com; 2016.

7. Katoh K, Rozewicki J, Yamada KD. MAFFT online service: multiple sequence alignment, interactive sequence choice and visualization. Brief Bioinform. 20:1160-1166; 2019.
8. Stamatakis A. RAxML version 8: a tool for phylogenetic analysis and post-analysis of large phylogenies. Bioinformatics 30:1312-1313; 2014.

9. Arenas M. Trends in substitution models of molecular evolution. Front Genet. 6:319; 2015.

10. Li L, Bowman AS, DeLiberto TJ, Killian ML, Krauss S, Nolting JM, Torchetti MK, Ramey AM, Reeves AB, Stallknecht DE, et al. Genetic evidence supports sporadic and independent introductions of subtype $\mathrm{H} 5$ low-pathogenic avian influenza A viruses from wild birds to domestic poultry in North America. J Virol. 92:e00913-18; 2018.

11. Drummond AJ, Rambaut A. BEAST: Bayesian evolutionary analysis by sampling trees. BMC Evol Biol. 7:214; 2007.

12. Minin VN, Bloomquist EW, Suchard MA. Smooth skyride through a rough skyline: Bayesian coalescent-based inference of population dynamics. Mol Biol Evol. 25:1459-1471; 2008.

13. Rambaut A, Drummond AJ, Xie D, Baele G and Suchard MA. Posterior summarisation in Bayesian phylogenetics using Tracer 1.7. Syst. Biol. 67:901-904; 2018

14. BEAST Developers: FigTree, version 1.4.4.: http://tree.bio.ed.ac. uk/software/figtree/; 2018.

15. Bandelt HJ, Forster P, Rohl A. Median-joining networks for inferring intraspecific phylogenies. Mol Biol Evol. 16:37-48; 1999.

16. Lee DH, Torchetti MK, Killian ML, Berhane Y, Swayne DE. Highly pathogenic avian influenza $A(H 7 N 9)$ virus, Tennessee, USA, March 2017. Emerg Infect Dis. 23:1860-1863; 2017.

17. Lee DH, Torchetti MK, Killian ML, Swayne DE. Deep sequencing of $\mathrm{H} 7 \mathrm{~N} 8$ avian influenza viruses from surveillance zone supports H7N8 high pathogenicity avian influenza was limited to a single outbreak farm in Indiana during 2016. Virology 507:216-219; 2017.

18. Xu Y, Ramey AM, Bowman AS, DeLiberto TJ, Killian ML, Krauss S, Nolting JM, Torchetti MK, Reeves AB, Webby RJ, et al. Low-pathogenic influenza $A$ viruses in North American diving ducks contribute to the emergence of a novel highly pathogenic influenza $\mathrm{A}(\mathrm{H} 7 \mathrm{~N} 8)$ virus. $J$ Virol. 91:e02208-16; 2017.

19. Seekings AH, Slomka MJ, Russell C, Howard WA, Choudhury B, Nunez A, Londt BZ, Cox W, Ceeraz V, Thoren P, et al. Direct evidence of H7N7 avian influenza virus mutation from low to high virulence on a single poultry premises during an outbreak in free range chickens in the UK, 2008. Infect Genet Evol. 64:13-31; 2018.

\section{ACKNOWLEDGMENTS}

Dong-Hun Lee was partially supported by the U.S. Government Interagency Agreement (60-6040-6-005). Xiu-Feng Wan was partially supported by the National Institutes of Health (R21AI135820). 